\title{
Bitemporal Postoperative Hemorrhage Following Pterional Craniotomy for the Treatment of an Internal Carotid Aneurysm
}

\section{Hemorragia bitemporal após craniotomia pterional para tratamento de aneurisma de carótida interna}

\author{
Leonardo Welling $^{1}$ Mariana Welling ${ }^{2}$ Eberval Gadelha Figueiredo ${ }^{3}$
}

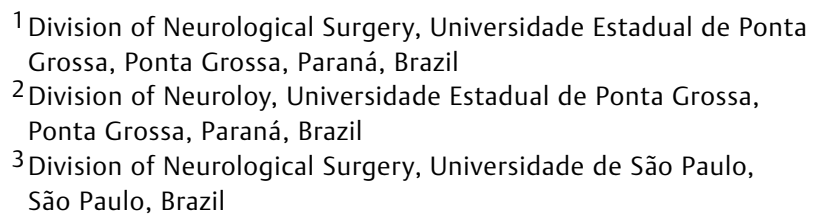

Address for correspondence Leonardo C. Welling MD, PhD, Division of Neurological Surgery. Universidade Estadual de Ponta Grossa, Paraná, Brazil (e-mail: leonardowelling@yahoo.com.br).

Arq Bras Neurocir 2017;36:29-31.

\begin{abstract}
Introduction Postoperative hemorrhage is a well-known complication after intracranial surgeries. It usually occurs at the site of the operation; however, there are many reports of cerebellar hemorrhage following supratentorial craniotomies. Despite that, there are only three cases of multiple postoperative supratentorial hemorrhages (distant from the site of the operation) following aneurysm clipping in the current literature.

Case Report A 52-year-old previously healthy woman underwent a left pterional craniotomy for the clipping of an unruptured aneurysm. The surgery was performed without any intraoperative rupture or other occurrences. On the follow-up computed tomography (CT) scan performed $24 \mathrm{~h}$ after surgery, bilateral posterior temporal lobe hematomas were identified, and they had no relation to the surgical site. The patient developed symptomatic vasospasm, with right-sided hemiparesis. This complication was treated conservatively, and the outcome was good.

Keywords

- cerebral aneurysm

- hemorrhage

- postoperative period

\section{Resumo \\ Palavras-chave \\ - aneurisma cerebral \\ - hemorragia \\ - período pós- operatório}

Conclusions Intracerebral hemorrhage far from the site of the craniotomy is an infrequent complication after neurosurgical procedures, especially in vascular neurosurgery. The present report warns of the occurrence of this entity even in asymptomatic patients.

Introdução Hemorragia pós-operatória é uma complicação bem conhecida após cirurgias intracranianas. Geralmente ocorre no sítio cirúrgico, porém há vários relatos de hemorragias cerebelares após craniotomias supratentoriais. Apesar disso, há somente três casos de hemorragias múltiplas supratentoriais (distantes do sítio cirúrgico) após clipagem de aneurisma intracraniano.
\end{abstract}

received

November 6, 2016 accepted

December 13, 2016
DOI http://dx.doi.org/ 10.1055/s-0037-1598600. ISSN 0103-5355.
Copyright (e 2017 by Thieme Revinter

Publicações Ltda, Rio de Janeiro, Brazil
License terms

(c) $(1) \$$ 
Relato do Caso Paciente feminina, de 52 anos, previamente hígida, foi submetida a craniotomia pterional para clipagem de aneurisma não roto. A cirurgia ocorreu sem ruptura intraoperatória ou outra intercorrência. Na tomografia de crânio de controle, realizada $24 \mathrm{~h}$ após o procedimento, 2 hematomas temporais posteriores foram identificados sem relação com o sítio cirúrgico. A paciente posteriormente desenvolveu vasoespasmo sintomático, com hemiparesia direita, mas essa complicação foi tratada conservadoramente, e teve boa evolução clínica, sem déficit residual.

Conclusões Hemorragias intracranianas distantes do sítio cirúrgico são complicações infrequentes, especialmente em neurocirurgia vascular. O presente caso adverte para a ocorrência dessa complicação mesmo em pacientes assintomáticos.

\section{Introduction}

Postoperative hemorrhage is a well-known complication after intracranial surgeries. ${ }^{1}$ It usually occurs at the site of the operation; however, there are many reports of cerebellar hemorrhage following supratentorial craniotomies. ${ }^{2}$ Out of all intracerebellar hemorrhages following supratentorial craniotomies, aneurysm clipping is involved in $32 \%$ of the cases. ${ }^{2}$ Despite that, there are only three cases of multiple postoperative supratentorial hemorrhages (distant from the site of the operation) following aneurysm clipping in the current literature. $^{1,2}$ In this report, the authors describe and discuss the possible pathophysiological events in this rare complication.

\section{Case Report}

A 52-year-old previously healthy woman had an isolated episode of seizure. During the evaluation, magnetic resonance angiography and conventional angiography were performed. A left posterior communicating aneurysm was identified (-Fig. 1). The patient underwent a left pterional craniotomy

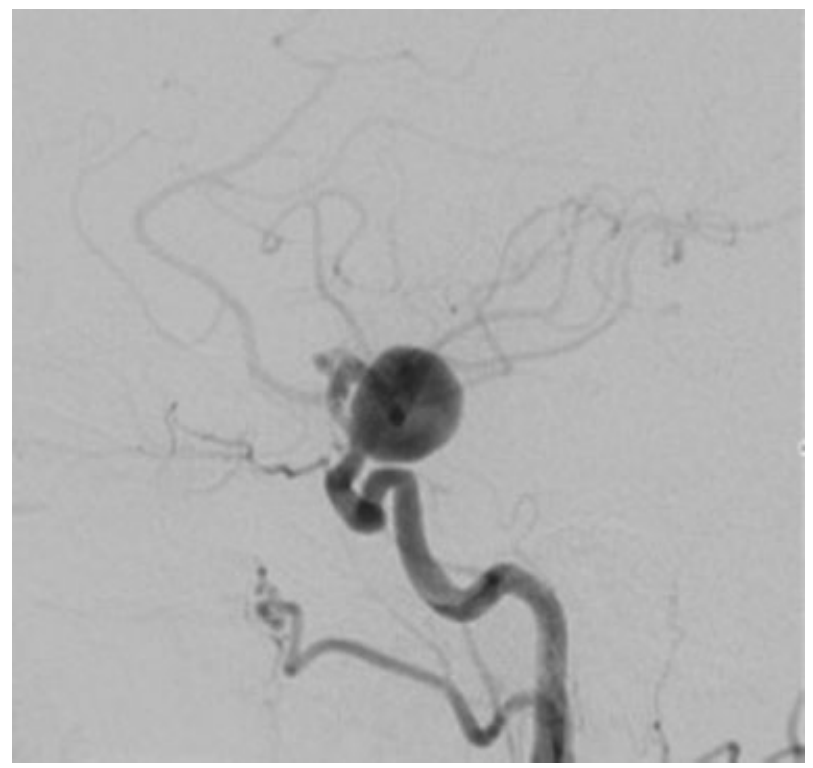

Fig. 1 Preoperative angiography. Left internal carotid aneurysm (posterior communicating segment). for aneurysm clipping that was performed without any intraoperative rupture or other occurrences. After the surgery, the patient was completely awake, and had no deficits.

On the follow-up computed tomography (CT) scan performed $24 \mathrm{~h}$ after surgery, bilateral posterior temporal lobe hematomas were identified, and they had no relation to the surgical site (-Fig. 2 ).

A complete hematological examination was performed, and the results were normal. During the follow-up, the CT scans showed the progressive reabsorption of both hematomas, but at the 12th postoperative day, the patient developed a symptomatic vasospasm with right-sided hemiparesis. This complication was treated conservatively, and the outcome was good.

\section{Discussion}

Intracerebral hemorrhage remote from the site of the craniotomy is an infrequent complication after neurosurgical procedures. $^{3}$ These hemorrhages are often worrying and life-threatening complications. ${ }^{2}$ Different mechanisms have been proposed, some authors consider that aggressive

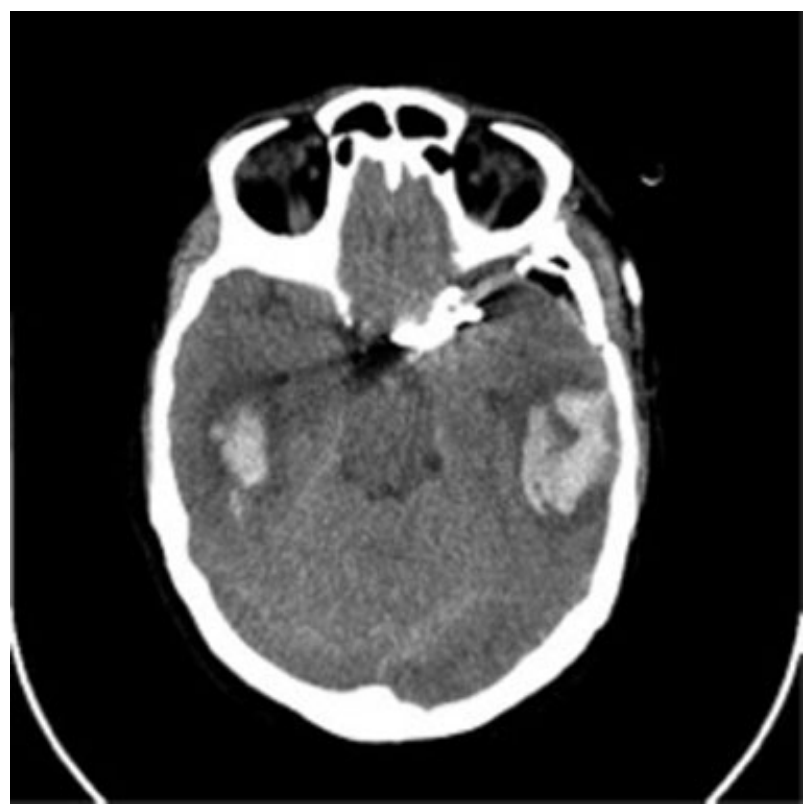

Fig. 2 Postoperative tomography. Bitemporal hemorrhage distant from the craniotomy site. 
intraoperative cerebrospinal fluid removal can cause a brain shift that contributes to intracerebral hemorrhages. Others suggest that the surgical procedure itself induces coagulative modifications. A history of hypertensive peaks during the recovery period is also involved in this scenario. $^{1-3}$

Despite the fact that none of the previously described pathophysiological mechanisms were involved in our case, the present study warns of the occurrence of this entity even in asymptomatic patients.

\section{References}

1 Fukamachi A, Koizumi H, Nukui H. Postoperative intracerebral hemorrhages: a survey of computed tomographic findings after 1074 intracranial operations. Surg Neurol 1985;23(06):575-580

2 Marquardt G, Setzer M, Schick U, Seifert V. Cerebellar hemorrhage after supratentorial craniotomy. Surg Neurol 2002;57(04):241-251 , discussion 251-252

3 Figueiredo EG, de Amorim RL, Teixeira MJ. Remote cerebellar hemorrhage (zebra sign) in vascular neurosurgery: pathophysiological insights. Neurol Med Chir (Tokyo) 2009;49(06):229-233, discussion 233-234 